\title{
Perancangan Sistem Informasi Surat Menyurat Terintegrasi (SUMATRI) Berbasis Website dan Android
}

\author{
Kadek Oky Sanjaya ${ }^{1}$, I Gede Bendesa Subawa ${ }^{2}$, I Kadek Andy Asmarajaya ${ }^{3}$ \\ 1,3 Universitas Hindu Indonesia \\ Denpasar, Indonesia \\ ${ }^{2}$ Universitas Pendidikan Ganesha \\ Singaraja, Indonesia \\ e-mail: kadekoki@unhi.ac.id, bendesa.subawa@gmail.com, andyasmarajaya@unhi.ac.id
}

\begin{abstract}
Abstrak
Pada era revolusi industri 4.0 ini peranan teknologi informasi sangat penting karena semua aktivitas/pekerjaan diharapkan dapat terselesaikan dengan cepat dan memperoleh hasil yang akurat dan optimal melalui teknologi digital. Sektor pemerintah maupun swasta diharapkan bisa memanfaatkan teknologi untuk menunjang dan mengoptimalkan kinerja masing-masing sektor sehingga mampu untuk memberikan pelayanan yang lebih baik kepada masyarakat. Sistem informasi surat-menyurat terintegrasi (SUMATRI) merupakan suatu sistem yang dikembangkan untuk menunjang kinerja administrasi surat menyurat. Sistem mampu mengelola data administrasi perkantoran mulai dari arsip data kependudukan, arsip data surat masuk, arsip data surat-menyurat bahkan mampu menerima pembuatan surat yang dipesan secara online melalui smartphone android. Pemesanan surat secara online bertujuan agar masyarakat yang ingin membuat surat tidak perlu datang lansung ke kantor pelayanan karena semua syarat-syarat yang diperlukan bisa dilengkapi dan diupload via smartphone android. Admin menerima pemberitahuan dan memvalidasi surat yang dipesan oleh masyarakat dan memberikan pemberitahuan/notifikasi kepada masyarakat jika suratnya sudah bisa diambil. Perancangan SUMATRI diharapkan mampu membantu pemerintah dalam memberikan pelayanan yang lebih baik terutama dalam hal administrasi surat-menyurat kepada masyarakat.
\end{abstract}

Kata kunci: SUMATRI, surat-menyurat terintegrasi, android

\begin{abstract}
In the era of the fourth industrial revolution or industry 4.0 the role of technology and information is very important because all activities / work are expected to be completed quickly and obtain accurate and optimal results through digital technology. The government and private sectors are expected to be able to use technology to support and optimize the performance of each sector so that they are able to provide better services to the community. The integrated correspondence information system (SUMATRI) is a system which is able to manage office administration data ranging from population data archives, incoming mail data archives, correspondence data archives and even is able to accept the making of letters ordered online through an android smartphone. Online mail order aims to make people who want to make a letter do not need to come directly to the service office because all the necessary conditions can be completed and uploaded via an android smartphone. Admin will receive notification and validate the letter ordered by the public and will give notification to the public if the letter can be retrieved. The design of SUMATRI is expected to be able to assist the government in providing better services, especially in terms of the administration of correspondence to the public.
\end{abstract}

Keywords : SUMATRI, integrated correspondence, android

\section{Pendahuluan}

Perkembangan teknologi informasi memang sudah tidak bisa terbendung lagi. Hampir disegala bidang baik pemerintahan maupun swasta semuanya sudah sangat tergantung dengan teknologi. Tidak bisa dipungkiri bahwa dengan adanya teknologi berupa aplikasi masyarakat jadi sangat terbantu dalam melaksanakan aktifitasnya. Aplikasi yang berfungsi 
mempermudah aktifitas masyarakat seperti contoh aplikasi Gojek, Grab, Tokopedia, Bukalapak dan aplikasi-aplikasi lain yang mampu memberikan pelayanan praktis kepada penggunanya.

Kegiatan atau proses menggunakan cara-cara konvensional masih terdapat di beberapa sektor, hal ini tentu dapat memperlambat kinerja instansi terkait. Kendala terkait proses/cara manual juga bertolak belakang dengan visi-misi pemerintah dalam perkembangan revolusi industri 4.0, dimana seluruh sektor baik pemerintah maupun swasta diharapkan mampu memanfaatkan teknologi untuk menunjang dan mengoptimalkan kinerja masing-masing sektor. Pada era revolusi industri 4.0 peranan teknologi informasi sangat penting karena semua aktivitas/pekerjaan diharapkan dapat terselesaikan dengan cepat dan memperoleh hasil yang akurat dan optimal melalui teknologi digital.

Kantor Kelurahan Karangasem adalah instansi pemerintah yang memiliki fungsi untuk memberikan pelayanan kependudukan terutama dalam hal pengurusan surat-surat bagi warganya. Pengolahan data kependudukan dan surat-menyurat di kantor Kelurahan Karangasem pelaksanaanya masih secara manual, ini tentu memperlambat kinerja pada instansi tersebut. Penyimpanan data yang masih memanfaatkan dokumen fisik, sangat rentang akan terjadinya kehilangan atau kerusakan data, terjadi pengulangan data yang diakibatkan tidak adanya pendataan secara sistematis atau tersistem. Efek lain yang ditimbulkan adalah lambatnya proses pengurusan surat-menyurat warga. Warga harus datang berkali-kali untuk mendapatkan surat yang ingin dibuatnya.

Sistem terkomputerisasi yang mampu menangani masalah data kependudukan, suratmenyurat serta pengarsipan sehingga kinerja pelayanan dan administrasi lebih baik dengan berbasis website dan android. Penelitian terkait yang pernah dilakukan diantaranya Sistem Informasi Kependudukan Kantor Desa Puput, Kecamatan Simpangkatih [1], Sistem Informasi Surat Masuk dan Surat Keluar Berbasi WEB di Jurusan Teknik Elektro Politeknik Negeri Malang [2], Sistem Informasi Berbasis Web Pada Desa Tresnomaju Kecamatan Negerikaton Kab. Pesawaran [3].

Penelitian ini bertujuan untuk merancang pelayanan kepada masyarakat dengan membuat sebuah Aplikasi Sistem Informasi Surat Menyurat Terintegrasi (SUMATRI) Berbasis Website dan Android. Sumatri merupakan sebuah sistem yang memuat informasi-informasi seputar profil perusahaan/instansi secara komplit termasuk berita terbaru, statistik kependudukan, Infografik penduduk dan yang menjadi perbedaan dengan penelitian-penelitian sebelumnya adalah terdapat sistem surat-menyurat yang tentunya dapat membantu baik itu dari sisi administrator perusahaan/instansi dalam melayani proses administrasi surat-surat dan bagi pengguna dapat memudahkan dalam proses pengajuan permohonan surat. Harapan peneliti dengan adanya sistem Sumatri yaitu dapat membantu instansi pemerintah maupun swasta mengoptimalkan dan mengefisienkan dalam memberikan pelayanan kepada masyarakat. Studi kasus penelitian ini adalah kantor Kelurahan Karangasem.

\section{Metodologi Penelitian}

Metode yang digunakan pada perancangan sistem informasi surat menyurat terintegrasi adalah metode SDLC-Waterfall [4]. Metode Waterfall sering disebut sebagai sebuah siklus hidup klasik atau classic life cycle, hal ini menjabarkan pendekatan secara sistematis dan terurut pada proses pengembangan perangkat lunak. Tahapan-tahapan yang dilalui dimulai dari spesifikasi kebutuhan pengguna, dilanjutkan ke tahapan desain sistem, implementasi, testing atau uji coba, kemudian ke tahap deployment atau pengujian dilapangan, sampai pada tahap pemeliharan atau Maintenance.

SDLC atau software development life cycle merupakan proses pengembangan atau pembaharuan suatu sistem perangkat lunak dengan penerapan model-model tertentu dan metodologi yang digunakan untuk mengembangkan sistem perangkat lunak sebelumnya [5].

Tahapan dalam metode SDLC - Waterfall adalah sebagai berikut: 


\section{SDLC- WATERFALL MODEL}

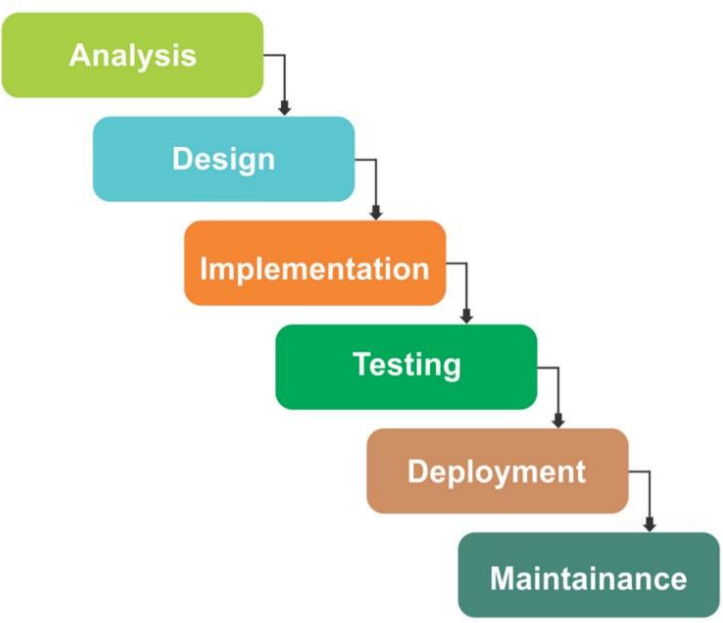

Gambar 1. Tahapan metode SDLC - Waterfall

1. Analysis atau Analisa Kebutuhan Sistem

Pada tahapan ini dilakukan pengumpulan data untuk dianalisis, sehingga didapatkan analisa akan kebutuhan dari system yang akan dibangun.

2. Design

Tahap desain dilakukan untuk membentuk sebuah rancangan desain system yang akan dibangun secara lengkap. Mulai dari desain antar muka sampai pada algoritma yang akan digunakan pada pembuatan sistem.

3. Implementation

Tahap implementasi mencakup pembuatan sistem, dalam hal ini desain sistem yang sudah dirancang di implementasikan menggunakan bahasa pemrograman tertentu untuk menghasilkan sistem yang lengkap.

4. Testing

Tahap testing ditujukan untuk melakukan pengujian pada sistem sebelum sistem disebarkan kepada pengguna untuk memastikan bahwa sistem yang dibuat sudah sesuai dengan desain yang telah dirancang.

5. Deployment

Tahap deployment dilakukan untuk menguji sistem ke level pengguna, untuk memastikan bahwa sistem yang dikembangkan telah sesuai dengan yang disepakati.

6. Maintenance

Tahap terakhir adalah maintenance, dimana setelah sistem selesai dikembangkan, maka diperlukan aktifitas pemeliharaan untuk memastikan bahwa sistem tetap bisa berjalan dengan baik.

\section{Kajian Pustaka}

\subsection{Surat Menyurat}

Surat menyurat merupakan suatu aktifitas antara satu pihak dengan pihak yang lain untuk mengadakan hubungan secara terus menerus. Pada umumnya kegiatanya suratmenyurat dilakukan secara manual dengan menggunakan metode pengiriman via pos. Namun seiring perkembangan teknologi, kegiatan surat-menyurat kini bisa dilakukan dengan lebih cepat dan aman menggunakan bantuan teknologi baik menggunakan e-mail, aplikasi sosial media maupun aplikasi-aplikasi terkait lainnya [2]. Sistem Informasi surat menyurat terintegrasi dirancang untuk mempermudah proses administrasi masyarakat dalam hal pengajuan permohonan surat. Alur proses dari sistem informasi surat menyurat sebagai berikut: 


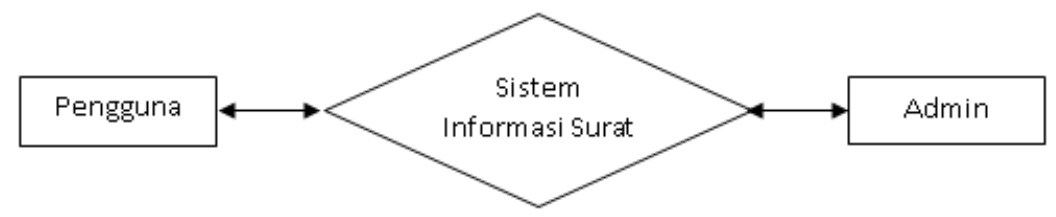

Gambar 2. Alur proses sistem informasi surat menyurat

Pada gambar 2. dijelaskan pengguna terlebih dahulu melakukan login pada sistem untuk melakukan pengajuan surat, admin selanjutnya menyetujui permohonan tersebut yang kemudian pada platform pengguna akan ditampilkan notifikasi bahwa surat sudah selesai dan bisa segera diambil.

\subsection{Website}

Website merupakan sekumpulan halaman yang memuat informasi-informasi tertentu yang berlokasi di suatu server atau hosting dan domain atau nama website yang bisa diakses secara luas dengan menggunakan media internet [1]. Ada 3 elemen penting yang wajib dalam sebuah website yaitu Domain, Hosting dan Konten. Tanpa itu semua maka website itu tidak akan pernah ditemukan oleh pengguna internet.

a. Domain

Domain merupakan nama dari sebuah website. Tujuan dari domain ini adalah untuk memudahkan pengguna menemukan website yang anda bangun.

b. Hosting

Hosting merupakan server atau tempat penyimpanan semua data baik itu script, database yang digunakan dalam pembuatan website.

c. Konten.

Kontek merupakan informasi yang terdapat pada website. Tanpa adanya konten maka website yang dibuat tidak akan memiliki manfaat apa-apa bagi pengguna.

\subsection{Android}

Android merupakan salah satu sistem operasi berbasis linux yang dikembangkan oleh perusahaan Google. Jika pada pc dikenal yang namanya sistem operasi windows, linux/ubuntu, MacOS, maka pada ponsel ada sistem operasi android dan ios. Perbedaan android dengan sistem operasi Windows 10 milik Microsoft bahwa Windows 10 mewajibkan perusahaan untuk membayar royalty untuk bisa menggunakan sistem tersebut. Banyak vendor yang bekerja sama dengan Google untuk bisa memanfaatkan sistem operasi android. Sebab, sistem yang dikembangkan dengan basis android bisa jalankan di berbagai smartphone. Berbeda dengan sistem operasi seperti iOS milik perusahaan Apple yang hanya dapat digunakan pada perangkat iPhone atau iPad.

\section{Hasil dan Pembahasan}

Penelitian ini merancang sebuah sistem informasi surat menyurat terintegrasi (SUMATRI). Adapun rancangan dalam pengembangan sistem sumatri adalah dimulai dengan merancang kebutuhan perangkat lunak, kebutuhan perangkat keras, rancangan diagram konteks, dan rancangan desain antar muka.

\subsection{Rancangan Kebutuhan Perangkat Lunak ( Software )}

Perangkat lunak (Software) yang dibutuhkan untuk menjalankan aplikasi yang dirancang pada mode emulator dan web antara lain :

1. Sistem Operasi Windows 10 Home Single Language

2. Android Studio

3. ADT (Android Development Tools)

4. Android SDK Versi 4.4.2

5. XAMPP

6. Adobe Dreamweaver CC 2015

7. Sublime Text 3

8. SQLyog

9. Genymotion include virtual box 


\subsection{Rancangan Kebutuhan Perangkat Keras (Hardware)}

Perangkat keras (hardware) yang dibutuhkan untuk menjalankan aplikasi pada mode emulator dan web antara lain:

1. Laptop Acer

2. Processor Intel(R) Core (TM) i3 CPU M380 @2.53GHz

3. RAM 4 GB

4. VGA Intel(R) HD Graphics

\subsection{Rancangan Diagram Konteks}

Berikut gambaran Data Flow Diagram yang digunakan dalam Perancangan Aplikasi Sistem Informasi Surat Menyurat Terintegrasi (SUMATRI) Berbasis Website dan Android.

a) Diagram konteks adalah bagian dari Data Flow Diagram yang digunakam memetakan model lingkungan dan dipresentasikan dengan lingkaran tunggal yang mewakili keseluruhan sistem [6]. Rancangan diagram konteks SUMATRI bisa dilihat pada Gambar 3.

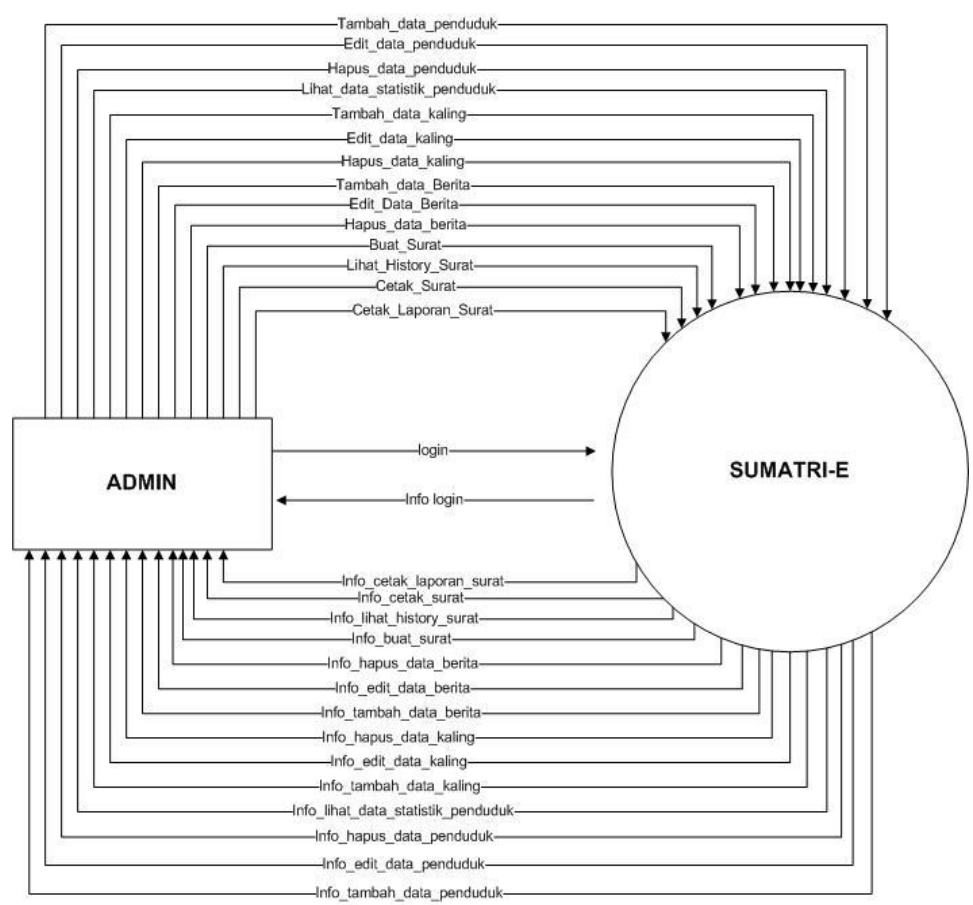

Gambar 3. Digram konteks SUMATRI

b) DFD (Data Flow Diagram) Level 0

Pada Data Flow Diagram (DFD) Level 0, Diagram Konteks dipecah menjadi beberapa proses yaitu, proses login, proses maintenance data penduduk, proses maintenance data berita dan proses maintenance data surat [7]. Rancangan DFD level 0 bisa dilihat pada Gambar 4. 


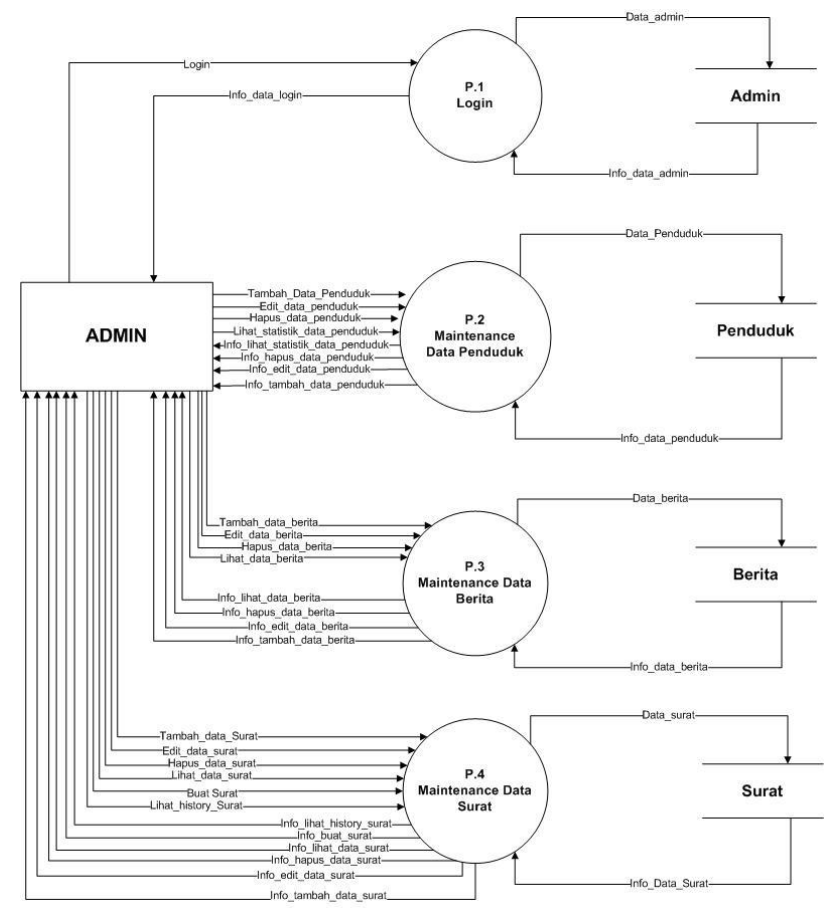

Gambar 4. Rancangan data flow diagram (DFD) level 0

c) Use Case Diagram

Usecase Diagram digunakan untuk menggambarkan secara khusus fungsionalitas dari sistem yang akan dibuat [8]. Diagram ini menjelaskan apa yang dapat dilakukan oleh sistem serta merepresentasikan interaksi atau hubungan yang terjadi antara aktor dengan sistem. Rancangan Use Case Digram bisa dilihat pada Gambar 5.

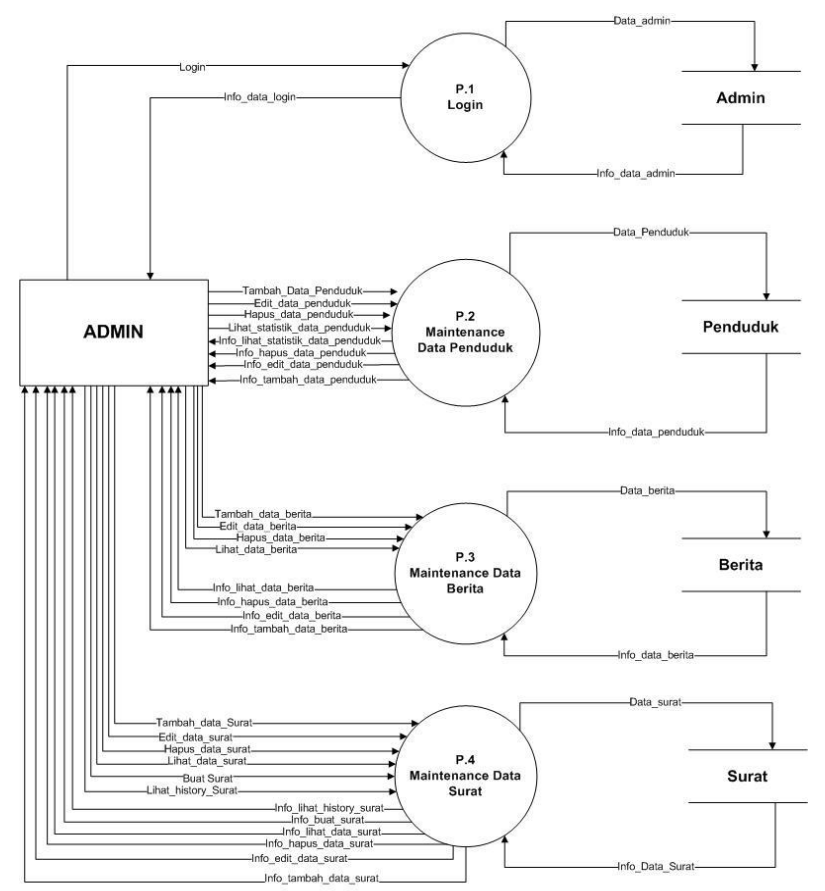

Gambar 5. Rancangan Use Case Diagram 


\subsection{Desain Antar Muka}

\subsubsection{Desain Tampilan Login Website}

Tampilan Login merupakan tampilan yang digunakan untuk login admin atau operator desa. Rancangan halaman login website bisa dilihat pada Gambar 6 .

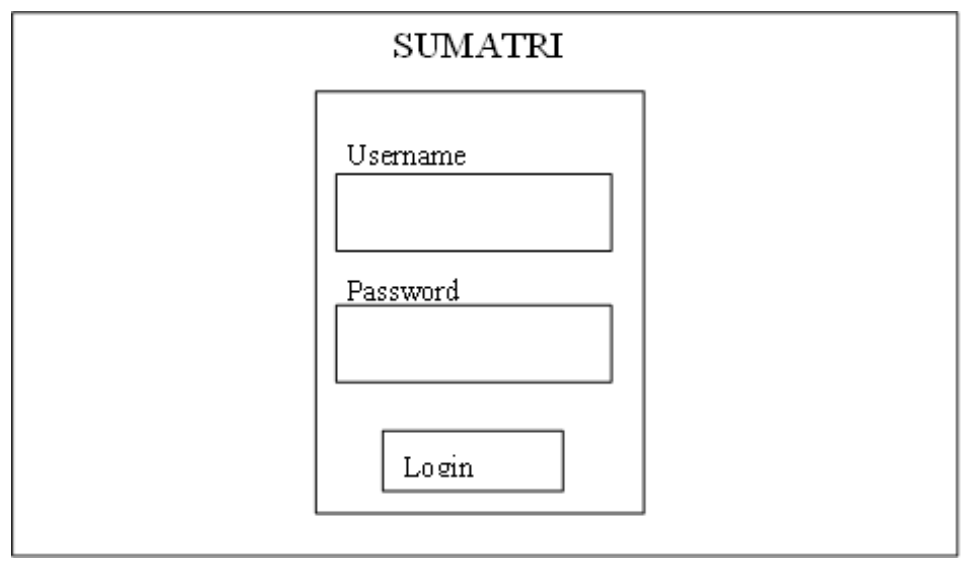

Gambar 6. Rancangan halaman login website

\subsubsection{Desain Tampilan Utama Website}

Tampilan utama website adalah tampilan awal yang terlihat setelah melakukan login. Rancangan halam utama website bisa dilihat pada Gambar 7.

\begin{tabular}{|c|c|}
\hline SUMATRI & DASHBOARD \\
\hline $\begin{array}{r}\text { Halaman } \\
\text { Administrator } \\
\end{array}$ & \\
\hline Dashboard & \multirow[t]{2}{*}{ Salam Pembuka } \\
\hline Masterdata & \\
\hline Master Penchuduk & \\
\hline Website & \\
\hline Surat Menyurat & \\
\hline
\end{tabular}

Gambar 7. Rancangan halaman utama website

\subsubsection{Desain Tampilan Tambah Admin}

Tampilan tambah admin berfungsi sebagai halaman untuk menambah admin baru atau operator. Rancangan halaman tambah admin SUMATRI bisa dilihat pada Gambar 8.

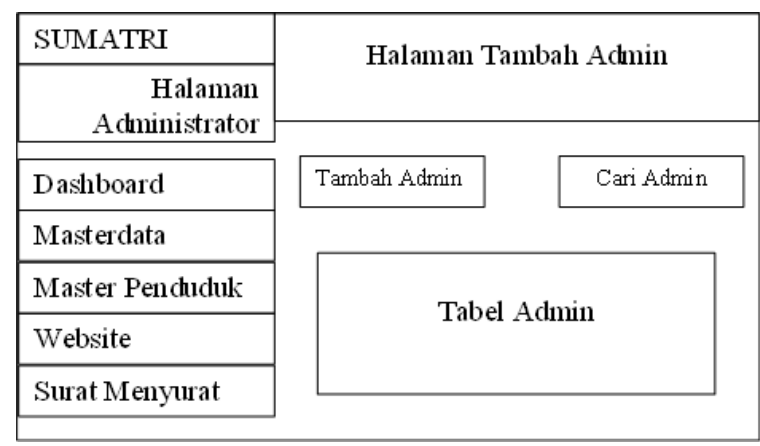

Gambar 8. Rancangan halaman tambah admin SUMATRI 


\subsubsection{Desain Tampilan Tambah Data Penduduk}

Tampilan data tambah penduduk merupakan untuk menambah dan mencari data penduduk. Rancangan halaman master data penduduk SUMATRI bisa dilihat pada Gambar 9.

\begin{tabular}{|l|c|}
\hline SUMATRI & Halaman Master Penduduk \\
Administrator & Halaman \\
\hline Dashboard & Tambah Penduduk \\
\hline Masterdata & Cari Penduduk \\
\hline Master Penduduk \\
\hline Website \\
\hline Surat Menyurat \\
\hline
\end{tabular}

Gambar 9. Rancangan halaman master penduduk SUMATRI

\subsubsection{Desain Tampilan Tambah Data Kepala Lingkungan}

Tampilan data tambah kaling merupakan halaman untuk menambah dan mencari data kepala lingkungan. Rancangan halaman data kaling bisa dilihat pada Gambar 10.

\begin{tabular}{|c|c|c|}
\hline SUMATRI & \multirow{2}{*}{\multicolumn{2}{|c|}{ Hal aman Data Kaling }} \\
\hline $\begin{array}{r}\text { Halaman } \\
\text { Administrator }\end{array}$ & & \\
\hline & & \\
\hline Dashboard & Tambah Kaling & Cari Kaling \\
\hline Masterdata & & \\
\hline Master Penduduk & \multirow{2}{*}{\multicolumn{2}{|c|}{ Tabel Data Kaling }} \\
\hline Website & & \\
\hline Surat Menyurat & & \\
\hline
\end{tabular}

Gambar 10. Rancangan halaman data Kaling

\subsubsection{Desain Tampilan Cetak Surat}

Cetak Surat merupakan halaman yang menampilkan data surat yang bisa di cetak. Rancangan halaman cetak surat bisa dilihat pada Gambar 11.

\begin{tabular}{|c|c|c|c|}
\hline SUMATRI & \multirow{2}{*}{\multicolumn{3}{|c|}{ Menu Cetak Surat }} \\
\hline $\begin{array}{r}\text { Halaman } \\
\text { Adhinistrator }\end{array}$ & & & \\
\hline Dashboard & Sarat I & Surat 2 & Surat 3 \\
\hline Masterdata & Surat 4 & Sunt S & Surat 6 \\
\hline Master Penduduk & & & \\
\hline Website & Surat 7 & Surat 8 & Suras 9 \\
\hline Surat Menyouat & Sark 10 & Surat 11 & Surat 12 \\
\hline
\end{tabular}

Gambar 11. Rancangan Data Cetak Surat 


\subsubsection{Desain Tampilan Histori Surat}

Tampilan histori surat merupakan halaman untuk menampilkan histori surat masuk dan keluar yang dibuat. Rancangan halaman histori surat bisa dilihat pada Gambar 12.

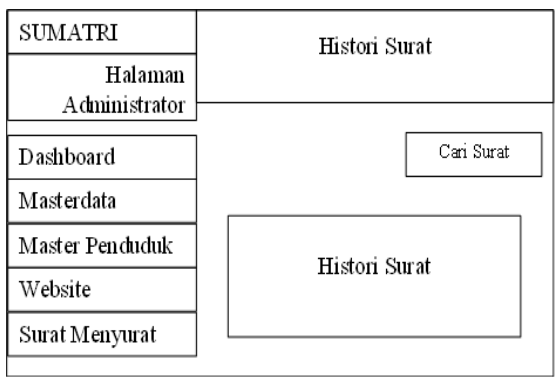

Gambar 12. Rancangan halaman histori surat

\subsubsection{Desain Tampilan Awal Android}

Tampilan awal android merupakan tampilan yang pertama kali muncul pada pengguna setelah melakukan login aplikasi. Rancangan tampilan awal android bisa dilihat pada Gambar 13.

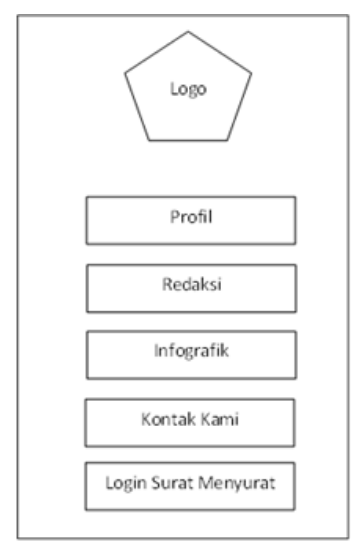

Gambar 13. Rancangan tampilan awal android

\subsubsection{Desain Tampilan Halaman Pesan Surat Android}

Tampilan halaman pesan surat merupakan halaman untuk menampilkan surat-surat yang bisa dipesan melalui android. Rancangan tampilan pesan surat online bisa dilihat pada Gambar 14.

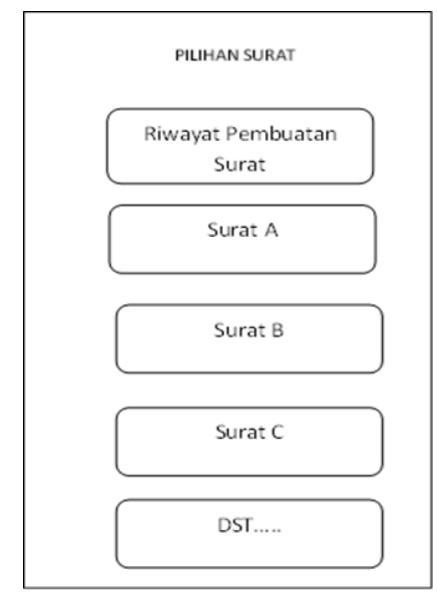

Gambar 14. Rancangan halaman pesan surat online 
Sistem Informasi Surat Menyurat terintegrasi dirancang untuk mempermudah pengguna dalam hal ini masyarakat dan staf kantor dalam pelaksanaan aktifitas pengajuan surat permohonan. Sistem ini dirancang dengan berbasis website dan android dengan desain yang user-friendly [6]. Dengan memanfaatkan teknologi cloud computing dan responsive web sehingga bisa diakses dari perangkat apapun. Dengan alur data yang terpadu dan terintegrasi yang tentunya memudahkan dalam proses control data.

\section{Kesimpulan}

Perancangan Sistem Informasi Surat Menyurat Terintegrasi (SUMATRI) berbasis web dan android dengan menggunakan metode SDLC-Waterfall. Perancangan sistem pada web dibuat dengan DFD (Data Flow Diagram), ERD (Entity Relationship Diagram) dan Konseptual Database. Website dirancang menggunakan software Visual Studio Code, Dreamweaver dan $X A M P P$. Perancangan aplikasi android dibangun menggunakan software Android Studio. Dengan menggunakan website dan android memudahkan pengguna untuk bisa mengakses dari perangkat apapun dan dimanapun.

\section{Daftar Pustaka}

[1]. Sujono, S. (2018). PENERAPAN APLIKASI SISTEM INFORMASI KEPENDUDUKAN BERBASIS WEB PADA KANTOR KEPALA DESA PUPUT KEC. SIMPANGKATIS. Simetris: Jurnal Teknik Mesin, Elektro Dan IImu Komputer. https://doi.org/10.24176/simet.v9i1.2078

[2]. Junus, M. (2018). SISTEM INFORMASI PENGELOLAAN SURAT MASUK \& SURAT KELUAR JURUSAN TEKNIK ELEKTRO POLITEKNIK NEGERI MALANG BERBASIS WEB MELALUI JARINGAN INTRANET POLINEMA. JURNAL ELTEK. https://doi.org/10.33795/eltek.v16i2.97

[3]. Santika Putra, M., Piarsa, I. N., \& Dwi Rusjayanthi, N. K. (2018). Rancang Bangun Sistem Informasi Web-Based Travel Assistant untuk Membantu Perjalanan Wisatawan. Jurnal Ilmiah Merpati (Menara Penelitian Akademika Teknologi Informasi). https://doi.org/10.24843/jim.2018.v06.i03.p08

[4]. Divayana, D. G. H., Adiarta, A., \& Abadi, I. B. G. S. (2017). Uji Coba Rancangan Model CSE-UCLA yang dimodifikasi dengan Metode Weighted Product dan Validasi Instrumen Evaluasi Layanan Perpustakaan Digital pada Perguruan Tinggi Komputer di Bali. Jl. Udayana Kampus Tengah.

[5]. Gede Jayeng Gotama, I. B., Kadek Ayu Wirdiani, N., \& Made Ika Marini Mandenni, N. (2019). Rancang Bangun Sistem Jual Beli Banten Online. Jurnal IImiah Merpati (Menara Penelitian Akademika Teknologi Informasi). https://doi.org/10.24843/jim.2019.v07.i02.p07

[6]. Prasetyo, N. D., Supratman, D., Fauzi, W. A. H., \& Murti, S. (2016). Perancangan Sistem Informasi E-Farming Berbasis Web untuk Mengetahui Tingkat Kelayakan Panen pada Sektor Pertanian. Seminar Nasional Aplikasi Teknologi Informasi.

[7]. STMIK Pringsewu, W., \& Aprilia, S. (2017). SISTEM INFORMASI BERBASIS WEB PADA DESA TRESNOMAJU KECAMATAN NEGERIKATON KAB. PESAWARAN. Jurnal TAM (Technology Acceptance Model).

[8]. Sudarmaji, S., \& Prasetyo, K. A. (2019). SISTEM INFORMASI PERKULIAHAN ONLINE PADA FAKULTAS ILMU KOMPUTER UNIVERSITAS MUHAMMADIYAH METRO LAMPUNG. Jurnal Nasional Pendidikan Teknik Informatika (JANAPATI). https://doi.org/10.23887/janapati.v8i1.14010 